\title{
Use of potato as carbohydrate source in poultry ration
}

\author{
Fowzia Sultana', Hafiza Khatun ${ }^{2}$ and Mohammad Amdad $\mathrm{Ali}^{3 *}$
}

\begin{abstract}
Potato is an extensively cultivated annual crop in Bangladesh. In some years, when the production of potato is surplus, tons of potatoes are damped due to insufficient storage facilities. This study aims at the use of potato in poultry rations that could greatly benefit the potato farmers and poultry industries. Potato meal was incorporated in rations of broiler (Cobb-500) and fayoumi laying hens, respectively. The rations were isonitrogenous and isocaloric, with the only difference being the content of corn and potato. The results showed there were no differences in feed conversion ratio, survivability rate and dressing percentage among the treatment groups of broiler up to $30 \%$ replacement of corn with potato. Furthermore, no notable difference was observed in egg production and egg quality of laying hens on potato diets. These results suggest that potato meal could be included up to $30 \%$ as substitute of corn meal in both broiler and laying hen diets without having any negative effects. We believe that the results from this study would significantly contribute to the nation where corn production is not as great as that of potato.
\end{abstract}

Keywords: Potato meal, Poultry feed, Production and quality of meat and egg, Broiler and laying hens

\section{Background}

Poultry meat and egg are the cheapest sources of highquality animal protein and good source of essential polyunsaturated fatty acids (PUFAs), especially rich in omega (n)-3 fatty acids [7]. Furthermore, meat contains lower level of fat compared to those of other animal protein. These factors contribute to the high demand for poultry meal and egg and motivate farmers to extend their present level of poultry farm and establish new one. However, cost of the poultry feed (70-80\% of total production cost) increases day by day and significantly affects the poultry production [18]. For the formulation of poultry feed, corn (cereal) is the conventional choice of carbohydrate sources due to its high energy, low fibre, higher palatability, and the presence of pigments and essential fatty acids [21]. It possesses about $50-70 \%$ portion in total diet. Inclusion of corn meets up to $70 \%$ energy and $30 \%$ protein-dietary requirements [21]. However, its applications for use in food industries (such as beverage, juice, soup, and sauce) in respect of human consumption and

\footnotetext{
*Correspondence: amdad53@yahoo.com

${ }^{3}$ Department of Agricultural Chemistry, Faculty of Agriculture,

Bangladesh Agricultural University, Mymensingh 2202, Bangladesh

Full list of author information is available at the end of the article
}

in biofuel have been expanding rapidly. These competing demands for the corn result in inadequate supply, thus leading to a high price of poultry products $[14,18]$.

To lower the production cost of poultry products (egg, meat, etc.), an alternative energy source for the poultry feed with lower cost has been investigated. Ideally, the ingredient should be able to substitute corn totally or partially and not have any negative impact on the efficiency and the cost of poultry production [3, 20]. Many alternative ingredients, such as water yam [5], cassava root meal [23, 24], pearl millet [1], sweet potato [9, 12, $18]$, etc. have been investigated and reported. It was also demonstrated that these cereals are deficient in certain essential amino acids, especially lysine and tryptophan, which are very important for the hens to grow healthily. $[18,21]$. Moreover, most of these available alternatives either suffer from processing complexity, such as mouldiness, and dustiness, or contain anti-nutrition factors, such as cyanogenic glycosides in cassava [23].

Our aim of this study is to find the usefulness of potato (Solanum tuberosum L.) as an alternative of corn. As far as nutritious value is concerned, it contains substantially greater amount of all essential amino acids, especially lysine [13]. Potato (fresh basis) contains approximately 
$20-25 \%$ dry matter with $12 \%$ crude protein (50\% pure) [18]. It contains reasonably high amounts of most amino acids but is deficient in tryptophan and sulphurcontaining amino acids [17]. It is to be noted that synthetic amino acids as supplement in dietary ration could be added to meet the feeding requirement. It is also an important source of both macro and micro minerals. Of the minerals, potassium, phosphorus, magnesium, sulphur, chlorine, iron, and zinc are found in larger quantities. Although calcium, phosphorus and iron are not present in significantly higher amounts, but even with limited contents, they can still provide important nutritional value to potato [4]. Potato also contains a variety of vitamin groups such as, A, B, C (27-36/100 mg) and I3, while cereal does not [4]. Recently, Mozafari et al. [18] reported that up to $25 \%$ maize can be replaced by potato meal in broiler ration, without inducing any negative affects on production performance. Except the above study, to the best of our knowledge, the potato meal as an alternative nutritious dietary source has not been investigated for the purpose of feeding laying hens for egg production. The present study therefore investigated the effects of potato meal on the quality and production of broiler meat as well as egg production of laying hens.

Moreover, potato is an extensively cultivated annual crop in Bangladesh showing higher productivity (16.68 $\mathrm{t} / \mathrm{ha}$ versus that of maize at $4.97 \mathrm{t} / \mathrm{ha}$ ) with shorter harvesting period ( 90 days for potato compared to 140 days for maize). As a result, the cost of potato is significantly lower (four times lower than corn) in Bangladesh [10, 11]. The production of potato is surplus in Bangladesh, and several tons of unused potato are dumped each year due to insufficient storage facilities. It would greatly benefit the potato farmers if potato could be used in poultry ration. It is worthy to note that $90 \%$ of corn is being imported into Bangladesh. This also leads to serious adverse effects on nation's gross domestic product (GDP). We believe that the results from this study would significantly contribute to the nation's GDP where corn production is not so great as that of potato.

\section{Methods}

The study was carried out at the Bangladesh Agricultural University, Mymensingh, Bangladesh during the period from July 2014 to December 2015. Good-quality, dustfree potatoes were collected from local market. They were then sliced, dried in sunlight and finally ground into meal by passing through a 1-mm screen using a WILEY MILL. Before determining the optimal formulation of ration, chemical analysis of potato meal $(5 \mathrm{~g})$ was performed according to methods of Association of Official Analytical Chemists (AOAC) [8] to measure nutrient values which are shown in Table 1 . All ingredients were weighed and then thoroughly mixed by hand at various dietary levels of potato according to each experimental treatment. The rations were isonitrogenous and isocaloric conforming to the recommendations by the NRC [19]. There was no restriction on feed and water consumption in the both experiments. This study includes two independent experiments. In the first experiment, effects of potato meal were investigated on broiler (Cobb500) rearing, which is assigned as "Experiment-1: Potato meal-fed broiler". Second experiment was performed to assess the egg production and egg quality of potato mealfed laying hens, which is assigned as "Experiment-2: Potato meal-fed laying hens".

\section{Experiment 1: potato meal-fed broiler Birds and rations}

Sixty-day-old white broiler (Cobb-500) chicks were divided into four groups. Each group consisted of five birds with three replications. On arrival, the chicks were wing-banded, weighed, and randomly placed into brooding pens. Good bedding materials, sufficient feeders and waterer's space per bird were provided. The brooding pens were equipped with two $250 \mathrm{~W}$ infrared fluorescent brooding lamps to maintain temperature in the brooder house. The starting temperature was $35{ }^{\circ} \mathrm{C}$ and then subsequently lowered at the rate of $5{ }^{\circ} \mathrm{C}$ per week until reaching finally the ambient temperature. Humidity level in the brooder house was ca. RH 75\%. After 2 weeks, the birds were transferred to a grower house (in floor). Ration formulations for starter and grower are presented in Table 2. For the four dietary treatment groups, corn was substituted with 0 (control), 20, 25 and $30 \%$ of potato meal, respectively. The starter ration was fed for the first 2 weeks, which was then continued with the grower ration for further 5 weeks. Body weights and feed intakes were recorded weekly for the entire study period.

\section{Slaughtering and processing}

Feed was withdrawn on day 35 , and the birds were slaughtered on day 36 . Body weights of 24-h-fasted birds were recorded. The birds were placed in killing cones, and

\begin{tabular}{ll}
$\begin{array}{l}\text { Table } 1 \text { Approximate composition of } \\
\text { matter basis) }\end{array}$ & Potato meal \\
\hline Components (\%) & meal (dry \\
\hline Energy (MJ/Kg) & 3220 \\
Water & 79 \\
Crude fibre & 4.9 \\
Crude protein & 2.8 \\
Ash & 1.4 \\
Ether extract & 0.21
\end{tabular}


Table 2 Compositions of boiler rations

\begin{tabular}{|c|c|c|c|c|c|c|c|c|}
\hline \multirow[t]{2}{*}{ Ingredients (\%) } & \multicolumn{4}{|c|}{ Starter diet (\% potato) } & \multicolumn{4}{|c|}{ Grower diet (\% potato) } \\
\hline & 0 & 20 & 25 & 30 & 0 & 20 & 25 & 30 \\
\hline Maize & 51.16 & 36.00 & 33 & 28.3 & 61.45 & 45.00 & 43.00 & 38.50 \\
\hline Potato meal & 0 & 20 & 25 & 30 & 0 & 20 & 25 & 30 \\
\hline Soybean meal & 41.71 & 37.5 & 35.8 & 35.3 & 31.63 & 29 & 27.5 & 27 \\
\hline Soybean oil & 3.38 & 3.8 & 3.6 & 3.8 & 3.1 & 3.2 & 2.8 & 2.8 \\
\hline DCP & 1.63 & 1.4 & 1.4 & 1.4 & 1.72 & 1.00 & 0.50 & 0.50 \\
\hline Limestone & 0.952 & 0.5 & 0.5 & 0.40 & 0.94 & 0.70 & 0.50 & 0.50 \\
\hline Vit. Min. pre & 0.25 & 0.20 & 0.20 & 0.20 & 0.25 & 0.25 & 0.20 & 0.20 \\
\hline Salt & 0.273 & 0.20 & 0.20 & 0.20 & 0.27 & 0.25 & 0.20 & 0.20 \\
\hline L-Lysine & 0.08 & 0.08 & 0.08 & 0.08 & 0.13 & 0.13 & 0.07 & 0.07 \\
\hline DL-methionine & 0.305 & 0.22 & 0.12 & 0.22 & 0.27 & 0.25 & 0.18 & 0.18 \\
\hline $\mathrm{NaHCO}_{3}$ & 0.23 & 0.10 & 0.10 & 0.10 & 0.23 & 0.22 & 0.05 & 0.05 \\
\hline Total & 100 & 100 & 100 & 100 & 100 & 100 & 100 & 100 \\
\hline
\end{tabular}

DCP digestible crude protein, Vit.Min. Pre vitamin mineral premix

their throats were cut to facilitate bleeding out. The birds were dipped in a scald for $30 \mathrm{~s}$ in hot water (at $62.8{ }^{\circ} \mathrm{C}$ ) to loosen the feathers. Then, the feathers were removed using a batch defeatherer, and skins were eviscerated. Chicken carcasses were thoroughly washed using water and weighed to obtain dressing percentages. Non-carcass components, such as lungs, liver, spleen, kidney, testicles, heart, and feet were separately weighed. Legs, thighs, and breasts were separated, vacuum-sealed, and stored in a refrigerator for further analyses.

\section{Experiment 2: potato meal-fed laying hens Birds and rations}

Twenty-four 16-week-old healthy fayoumi (ready-to-lay) birds were divided into four groups. Each group consists of two birds with three replications, and all the birds were randomly assigned to an individual cage in an environmentally controlled room with a $16-\mathrm{h}$ photoperiod. Four dietary treatments of potato meal replacing 0 (control), 20,25 and $30 \%$ of the corn in the diets, respectively, were implemented during the experimental period of 14 weeks (30-44 weeks of age). The rations (shown in Table 3) were formulated according to the NRC [19] recommendation.

\section{Egg production performance and quality}

Egg production was recorded daily, and feed consumption was recorded weekly throughout the experiment. Eggs from each group were collected biweekly to measure egg weight, shell-breaking strength, shell thickness, shell ratio, albumen ratio, yolk ratio, yolk colour and Haugh units. Egg weight was measured using an electronic digital balance. Shell-breaking strength was measured using an eggshell strength instrument (accuracy:
$0.1 \mathrm{~kg} / \mathrm{cm}^{2}$, Fujihira Industry Co., Ltd.). Individual egg was broken on a flat metal plate to measure the thickness of the albumen. Weights of albumen, egg yolk and eggshell were measured using an electronic digital balance. After removing the shell membrane, the shell thickness was measured using a dial gauge (Peacock, Tokyo, Japan) at three locations on the egg (air cell, equator and sharp end), and an average value of the three measurements was recorded. Yolk colour was measured using a Roche Yolk Colour Fan (Roche Ltd., Basel, Switzerland). The shell ratio, albumen ratio, yolk ratio and Haugh units were calculated according to the following formulas:

$$
\begin{aligned}
& \text { Shell ratio }=\frac{\text { Shell weight } \times 100}{\text { Egg weight }} \\
& \text { Albumen ratio }=\frac{\text { Albumen weight } \times 100}{\text { Egg weight }} \\
& \text { Yolk ratio }=\frac{\text { Yolk weight } \times 100}{\text { Egg weight }} \\
& \text { Haugh units }=100 \log \left(H-1.7 W^{0.37}+7.6\right),
\end{aligned}
$$

where $H$ and $W$ are the observed height of albumen (mm) and the weight of each egg $(\mathrm{g})$, respectively.

\section{Statistical analysis}

All the recorded and calculated parameters were compared among different dietary combinations in a factorial experiment in a completely randomized design (CRD) performing ANOVA, and LSD was used to compare the significant differences among different diets by analysing data using the computer package GENSTAT. 
Table 3 Compositions of dietary rations for laying hens

\begin{tabular}{|c|c|c|c|c|}
\hline \multirow[t]{2}{*}{ Variable } & \multicolumn{4}{|c|}{ Laying hens diet (\% potato) } \\
\hline & 0 & 10 & 20 & 30 \\
\hline Maize & 58.5 & 50.50 & 47 & 42.5 \\
\hline Potato meal & 0.00 & 10.00 & 20 & 30 \\
\hline Rice polish & 17 & 17.00 & 12 & 9 \\
\hline Soybean meal & 17 & 15.00 & 14 & 12 \\
\hline Lime stone & 7 & 7 & 6.5 & 6 \\
\hline Common salt & 0.25 & 0.25 & 0.25 & 0.25 \\
\hline Premix & 0.25 & 0.25 & 0.25 & 0.25 \\
\hline \multirow[t]{2}{*}{ Total } & 100 & 100 & 100 & 100 \\
\hline & $M E=2845, C P=15 \%$ & $M E=2818, C P=14.7 \%$ & $M E=2808, C P=14.62 \%$ & $M E=2804, C P=14.24 \%$ \\
\hline
\end{tabular}

NB: NRC recommendation $\rightarrow$ [19], Fayoumi Ration (Laying hens)

$M E$ metabolizable energy, $C P$ crude protein

\section{Results}

\section{Experiment 1: potato meal-fed broiler}

Effects of potato meal on production and growth performance of broiler are presented in Table 4. Significant $(P<0.01)$ difference was observed in body weight gain and feed intake among the treatment groups. Higher body weight of the birds was found in control group and with the increasing potato meal portion in the diets, the body weight of the birds decreased linearly, while food intake showed the opposite trend. This observation questions the nutrient utilization of potato by the broilers. Feed conversion ratio of the birds also linearly decreased with the potato meal in the diets. Importantly, no mortality was occurred in this study. Dietary treatments have no notable effects on dressing percentage and weights of other carcass components, such as breast, thigh, drumstick, wing etc., except abdominal fat $(P<0.01)$ as shown in Table 4. Significantly low abdominal fat $(\sim 4$ times lower than that of control groups) was found in all the potato meal-fed birds.

\section{Experiment 2: potato meal-fed laying hens}

The effects of potato meal on the egg production of laying hens with the ages ranging from 30 to 44 week are presented in Table 5. Physical parameters, such as feed consumption, egg mass, feed conversion ratio, feed cost, egg production, egg weight and survivability, were found to be similar among the treatment groups. The statistical differences were recorded only regarding the feed cost. The feed cost was slightly lower when the portion of potato was increased in the feed. The quality of eggs was also assessed, and it was observed that eggshell thickness, shape index, shell weight, shell percentage, egg-breaking strength, albumen index, yolk index, Haugh unit and yolk colour score were all non-significant for all the treatment groups (Table 5).

\section{Discussion}

\section{Experiment 1: potato meal-fed broiler}

In our study, the control group gained the highest body weight, and it likely decreases slightly with the increasing potato meal, even though the feed intake increases with the potato meal ratio. It might be due to poor nutrient utilization of potato meal. Some reported results in the literature suggested that the inclusion of sweet potato meal in broiler ration causes poor utilization of nutrient compared with maize-based diets [16, 25], thus leading to a lower body weight gain of bird. This might be responsible for the inversely linear fashion body weight gain with the amount of sweet potato meal [3]. In contrast, some other studies, with feeding $25 \%$ potato to starter birds [18], $50 \%$ sweet potato to broiler starter [9], 36 and $45 \%$ sweet potato to starter and finisher birds, respectively $[3,26]$, reported that either potato or sweet potato in diets did not affect the body weight gain, food conversion ratio, or mortality percentages. Furthermore, we have found that dietary treatments have no notable effects on the dressing percentage and the weights of other carcass components, such as breast, thigh, drumstick, wing etc., except abdominal fat $(P<0.01)$. These results are in agreement with those in the reported literature [18] on driedcooked potato meal diets up to $35 \%$.

A point to be noted is that the abdominal fat percentage decreases with the increasing potato meal. Since the fats in other limbs in hens is related to the abdominal fat content, it can be said that the fat contents in other limbs of meat are lower as well, compared to those of the control group. We speculated that high fibre content plays a crucial role in this regard. The significance of this result is twofold. First, the lower weight of dressing is likely due to the low content of fat. Second, the reduced fat in meat is definitely of more worth in terms of fetching higher 
Table 4 Effect of dietary potato meal on growth performance and meat yields of broiler

\begin{tabular}{|c|c|c|c|c|c|}
\hline \multirow[t]{2}{*}{ Parameter } & \multicolumn{4}{|c|}{ Potato content (\%) } & \multirow[t]{2}{*}{ Level of significance } \\
\hline & 0 & 20 & 25 & 30 & \\
\hline Body weight (g/broiler) & $1247.88^{\mathrm{a}}$ & $1033.33^{c}$ & $1013.96^{d}$ & $1106.25^{b}$ & $* *$ \\
\hline Body weight gain (g/broiler) & $923.47^{\mathrm{a}}$ & $719.54^{c}$ & $692.85^{d}$ & $787.58^{b}$ & ** \\
\hline Feed intake (g/broiler) & $2050.46^{d}$ & $2096.06^{c}$ & $2172.56^{b}$ & $2228.92^{\mathrm{a}}$ & ** \\
\hline FCR & $2.41^{\mathrm{b}}$ & $2.91^{\mathrm{a}}$ & $3.15^{\mathrm{a}}$ & $2.83^{\mathrm{a}}$ & $0.0039^{* *}$ \\
\hline Survivability (\%) & 100 & 100 & 100 & 100 & NS \\
\hline Body weight ( $\mathrm{g} / \mathrm{broiler}$ ) of slaughtered bird & $1293.85^{\mathrm{a}}$ & $1057.60^{c}$ & $1021.28^{c}$ & $1142.33^{b}$ & ** \\
\hline Thigh weight & $10.50^{\mathrm{a}}$ & $9.09^{b}$ & $9.88^{\mathrm{ab}}$ & $9.44^{\mathrm{ab}}$ & 0.111 \\
\hline Drumstick weight & 8.51 & 8.13 & 8.38 & 8.80 & 0.745 \\
\hline Wing weight & 7.98 & 7.73 & 7.87 & 8.08 & 0.804 \\
\hline Breast weight & 9.40 & 9.04 & 9.63 & 8.96 & 0.2050 \\
\hline Abdominal fat & $0.84^{\mathrm{a}}$ & $0.18^{c}$ & $0.30^{\mathrm{b}}$ & $0.18^{c}$ & $* *$ \\
\hline Dressing & $61.01^{\mathrm{ab}}$ & $56.09^{b}$ & $62.69^{a}$ & $59.16^{\mathrm{ab}}$ & 0.0690 \\
\hline
\end{tabular}

$\overline{\mathrm{a}, \mathrm{b}, \mathrm{c}, \mathrm{d}}$ Means within a row with different superscripts are significantly different $(P<0.01)$

NS non-significant, $g$ gram

** $\mathrm{P}<0.01$, significant at $1 \%$ level

Table 5 Egg production performance and egg quality of laying hen for a period of 14 weeks (30-44 weeks of age)

\begin{tabular}{|c|c|c|c|c|c|}
\hline \multirow[t]{2}{*}{ Parameter } & \multicolumn{4}{|c|}{ Potato content (\%) } & \multirow[t]{2}{*}{ Level of significance } \\
\hline & 0 & 10 & 20 & 30 & \\
\hline Feed consumption (g/b/d) & 105.14 & 105.42 & 104.95 & 105.07 & $0.58^{\mathrm{NS}}$ \\
\hline Egg mass production (g/h/d) & 48.10 & 46.57 & 43.31 & 46.08 & $0.55^{\mathrm{NS}}$ \\
\hline Feed conversion ratio & 2.19 & 2.27 & 2.45 & 2.28 & $0.54^{\mathrm{NS}}$ \\
\hline Feed cost (Tk/kg egg) produced & 33.46 & 33.10 & 32.84 & 32.46 & $<0.0001^{* *}$ \\
\hline Feed cost (hen/d) & 3.52 & 3.49 & 3.45 & 3.41 & $<0.0001^{* *}$ \\
\hline Egg production (\%) & 57.07 & 53.81 & 51.99 & 52.90 & $0.45^{\mathrm{NS}}$ \\
\hline Egg weight (g/egg) & 40.14 & 39.29 & 40.06 & 39.02 & $0.81^{\mathrm{NS}}$ \\
\hline Survivability (\%) & 100 & 100 & 100 & 100 & $0.00^{\mathrm{NS}}$ \\
\hline Shell thickness (mm) & 0.38 & 0.35 & 0.38 & 0.37 & $0.33^{\mathrm{NS}}$ \\
\hline Shape index & 78.32 & 79.03 & 78.23 & 79.09 & $0.22^{\mathrm{NS}}$ \\
\hline Shell weight (g/egg) & 4.18 & 4.29 & 3.96 & 4.22 & $0.41^{N S}$ \\
\hline Shell (\%) & 10.35 & 10.67 & 10.26 & 11.22 & $0.12^{\mathrm{NS}}$ \\
\hline Egg breaking strength & 1500.90 & 1504.77 & 1500.95 & 1506.01 & $0.11^{\mathrm{NS}}$ \\
\hline Albumen index & 0.10 & 0.10 & 0.11 & 0.09 & $0.18^{\mathrm{NS}}$ \\
\hline Yolk index & 0.46 & 0.48 & 0.45 & 0.46 & $0.50^{\mathrm{NS}}$ \\
\hline Haugh unit & 89.73 & 90.67 & 88.16 & 88.70 & $0.28^{N S}$ \\
\hline Yolk colour score & 8.17 & 9.67 & 9.00 & 8.50 & $0.34^{\mathrm{NS}}$ \\
\hline
\end{tabular}

$N S$ non-significant, $g$ gram, $b$ bird, $d$ day, $h$ hen, $m m$ millimetre

** $\mathrm{P}<0.01$, significant at $1 \%$ level

market prices since high animal fat causes elevated blood cholesterol leading to atherosclerosis or heart failure [6]. A detailed investigation is required to relate the fat content in meat to the fibre in diet. It is also suggested to find an optimal level of potato meal in broiler diets to maintain the fat content in poultry meat within acceptable limits.

\section{Experiment 2: potato meal-fed laying hens}

Inclusion of potato slightly reduced the feed cost, although egg production and quality were statistically insignificant and found to be similar among the treatment groups. A slightly higher egg production and better feed conversion ratio were observed in the control group, which might be due to the high feed intake of hens 
compared to the potato meal-fed hens. Again, this lower egg production may be due to the high fibre content in potato meal arising from the poor nutrient utilization by birds. Direct comparison of production performance and egg quality cannot be made since, to the best of our knowledge, there is no report in the literature investigating the effects of potato meal on the egg production of laying hens. However, the results are in agreement with some of the studies with sweet potato used as a substitute for maize. Ladokun and Tewe [15] reported that egg production reduced due to the high fibre content of sweet potato and the low protein utilizations by birds fed on sweet potato meal diet. They also suggested that sun-dried sweet potato meal at a substitution rate of $50 \%$ can safely replace maize in the diets of laying hens without any negative effect on egg production. In contrast, Sobamiwa [22] did not observe any significant difference in the cumulative egg production when sweet potato was incorporated up to $20 \%$ in the diets of laying hens. Afolayan et al. [2] also reported that 20\% replacement of maize in the diets of laying hens with sweat potato meal led to no significant differences in the feed costs per $\mathrm{kg}$ of egg production and laying performances.

\section{Conclusions}

The results in this study suggested that there were no significant differences in meat production or meat quality among the treatment groups of broiler with up to $30 \%$ replacement of corn with potato. Furthermore, no significant difference was observed on either egg production or egg quality of laying hens fed on potato meal diets. These results suggested that potato meal could be safely included up to $30 \%$ as replacement of corn meal in both diets of broiler and laying-hens, without causing any negative effects on the production performance. However, we were able to reduce the production cost by up to $4 \%$. These results would encourage the farmers of the country where price of potato is lower than that of corn. Importantly, we found the benefit of a low content of fat in potato meal-fed broilers. We believe that the results from this study will play a crucial role in the further development of low-fat poultry meat.

\section{Authors' contributions \\ FS developed the experiment design and most of the laboratory analysis, interpretation of the results and manuscript writing. HK offered advice dur- ing the development of the experiment, interpretation of the results and manuscript writing. MAA provided general conception and interpretation of results and manuscript writing. All the authors read and approved the final manuscript.}

\section{Authors' information}

FS is a professor at the Department of Poultry, Bangladesh Agricultural University, Bangladesh. She holds a Bachelor degree in Animal Husbandry, and M.Sc. and Ph.D. in poultry science. She spent some of her research time at the University of Hawaii, USA during her postdoctoral research. She has to her credit more than 15 years of research experience and 14 years of teaching experience at the graduate and post-graduate levels. She is specialized in poultry digestive and reproduction system. Her articles have been published in more than 10 international journal publications. She has been a guide to many M.Phil. and Ph.D. students. HK has received her Bachelor degree in Animal Husbandry and Master degree in Animal Science from the Bangladesh Agricultural University, Bangladesh. Subsequently she involved herself as an Assistant Professor at the same Department. She is currently on study leave for pursuing her M.Sc. \& Ph.D. degree in Animal Science at the Saga University, Japan under Japanese government (Monbukagakusho) scholarship. Her specialization is on animal reproduction and biotechnology. MAA is an assistant professor at the Department of Agricultural Chemistry at the Bangladesh Agricultural University, Bangladesh. He is currently on leave and working as a Postdoctoral Research Associate at the University of Illinois at UrbanaChampaign,USA. He received his Ph.D. degree in Physical Chemistry from the University of Queensland, Australia, after his postgraduate Master degree in Advanced Materials Engineering from the Kookmin University, South Korea and his Bachelor degree in Chemistry from the University of Dhaka, Bangladesh. He was awarded with an International Postgraduate Research Scholarship and University of Queensland Centennial Scholarship for Ph.D. study and had obtained a fellowship provided by the Ministry of Science and Technology/Korea Science and Engineering Foundation to support his Master degree. His research interest involves the fundamental understanding of the physical properties of materials. He is credited with publications in more than twenty international journals that include Nature Communications (IF 11.329), Chemical Communications (IF 6.56), Carbon (IF 6.19), Sensors and Actuator B: Chemical (IF 4.75), ChemPhysChem (IF 3.13).

\section{Author details}

${ }^{1}$ Department of Poultry Science, Faculty of Animal Husbandry, Bangladesh Agricultural University, Mymensingh 2202, Bangladesh. ${ }^{2}$ Department of Animal Science, Faculty of Animal Husbandry, Bangladesh Agricultural University, Mymensingh 2202, Bangladesh. ${ }^{3}$ Department of Agricultural Chemistry, Faculty of Agriculture, Bangladesh Agricultural University, Mymensingh 2202, Bangladesh.

\section{Acknowledgements}

This study was supported by the Bangladesh University Grand Commission (UGC) and the Ministry of Science and Information \& communication Technology, Government of Peoples`Republic Bangladesh.

\section{Competing interests}

The authors declare that they have no competing interests.

Received: 3 August 2016 Accepted: 5 November 2016 Published online: 14 November 2016

References

1. Abd-Elrazig SM, Elzubeir EA. Effects of feeding pearl millet on laying hen performance and egg quality. Anim Feed Sci Technol. 1998:76:89-94.

2. Afolayan SB, Dafwang II, Tegbe TSB, Sekoni A. Effect of dietary maize substitution with sweat potato meal on performance of growers (10-22 weeks) and subsequent egg production (23-35 weeks). Asian J Poult Sci. 2013;7:55-64.

3. Agwunobi LN. Performance of broiler chickens fed sweet potato mea (Ipomea batatas L.) diets. Trop Anim Health Prod. 1999;31:383-9.

4. Ahmed KU. Potatoes for the tropics. Dhaka; 1977.

5. Aina ABJ, Animo AO. Substitution of maize with cassava and sweet potato meal as the energy source in the rations of laying hens. Pertanika J Trop Agric Sci. 1997;20:163-7.

6. American Medical Association. Diet and coronary heart disease: a joint policy statement of the AMA council on feeds and nutrition and food and nutrition board of the national academy of sciences. National Research Counciln. JAMA. 1977:222:1647.

7. Anonymous. Poultry and product annual. EU-28 Poultry sector to grow again 2013-14. Required report: public distribution; 2013.

8. AOAC. Official methods of analysis. 16th ed. Arlington: Association of Official Analytical Chemistry; 1995. 
9. Ayuk EA, Essien A. Growth and haematological response of broiler chicks fed graded levels of sweet potato (Ipomoea batata) meal as replacement for maize. Int J Poult Sci. 2009:8:485-8.

10. Azimuddin MD, Alam QM, Baset MA. Potato for food security in Bangladesh. Int J Sustain Crop Prod. 2009;4(1):94-9.

11. BBS. Yearbook of Agricultural Statistics of Bangladesh. Bangladesh Bureau of Statistics, Statistics Division, Ministry of Planning, Government of People's Republic of Bangladesh, Dhaka; 2012.

12. Beckford RC, Bartlett IR. Inclusion levels of sweet potato root meal in the diet of broilers I. Effect on performance, organ weights, and carcass quality. Poult Sci. 2015:94(6):1316-22

13. Danielle Donnelly PHD, Stan Kubow PHD. Role of potato in human health. Montréal: Plant Science Department \& School of Dietetics and Human Nutrition. McGill University; 2011.

14. Kreutzer DW. Renewable fuel standard, ethanol use, and corn prices. Background, heritage foundation; 2012; No. 2727.

15. Ladokun OA, Tewe OO. Sweet potato as a feed resource for layer production in Nigeria. J Poult Sci. 2003;83:56-61.

16. Maphosa T, Gunduza KT, Kusina J, Mutungamiri A. Evaluation of swee potato tuber (Ipomeabatatas I.) as a feed ingredient in broiler chicken diets. Livestock Research Rural Development; 2003.

17. Morrison FB. Feeds and feeding. Iowa: Morrison Publishing Company; 1961

18. Mozafari O, Ghazi S, Moeini MM. The effects of differen levels of edible potat (Solanumtubresum) replacing maize on performance, serum metabolite and immune system of broiler chicks. Iran J. Anim. Sci. 2013;3(3):583-8.
19. National Research Council. Nutrient requirements for poultry. Washington, DC; 1994

20. Ojewola GS, Olojede AO, Ehiri CG. Evaluation of Livingston potato/ Rizga (Plectranthusesculentus N.Br) and Hausa potato (Solenostemon rotundifolius Poir) as energy sources for broiler chicken. J Anim Vet Adv. 2006;5:472-7

21. Panda K, Zaidi PH, Rama rao SV, Raju MV. Efficacy of quality protein maize in meeting energy and essential amino acid requirements in broiler chicken production. J Appl Anim Res. 2014;42(2):133-9.

22. Sobamiwa $O$. The effect of replacing maize with dried sweet potatoes on the performance of layers. Niger J Anim Prod. 1988;15:99-102.

23. Sultan F, Ali MA, Jahan I. Growth performance meat yield and profitability of broiler chickens fed diets incorporating cassava tuber meal. J Environ Sci Nat Resour. 2012;5(1):47-53.

24. Sultana F, Khatun MF, Ali MA. Effect of dietary cassava tuber meal on egg production and egg quality of laying hen. Int J BioRes. 2011;2:1-4.

25. TEWE OO. Sweet potato utilisation in poultry diets, Tropic root crops. a developing economy. Proceedings of the Ninth Symposium of the International Society for Tropical Roots Crops. Accra Ghana; 1991. p. 426-35.

26. Turner WJ, Malynicz GL, Nad H. Effect of feeding rations based on cooked sweet potato and a protein supplement to broiler and crossbreed poultry. Papua New Guinea Agric. J. 1976;27(3):69-72.

\section{Submit your manuscript to a SpringerOpen ${ }^{\circ}$ journal and benefit from:}

- Convenient online submission

- Rigorous peer review

- Immediate publication on acceptance

- Open access: articles freely available online

High visibility within the field

- Retaining the copyright to your article 